\title{
THE CONSUMER AND THE PAROL EVIDENCE RULE: SECTION 2-202 OF THE UNIFORM COMMERCIAL CODE
}

\author{
RICHARD F. BROUDE* \\ I. INTRODUCTION
}

It may be an overstatement to say that the American credit economy is based upon the triad of the holder-in-due-course, the parol evidence rule, and the time-price doctrine. ${ }^{1}$ However, for consumers seeking to avoid paying for shoddy merchandise pursuant to installment sales contracts which provide for burdensome "carrying charges," the statement is not far from the truth. These bulwarks of a creditor-oriented economy have contributed more to consumer frustration, anger, and oppression than perhaps any other common law doctrines. Thus it is not surprising that these concepts have recently come under an accelerating assault. The time-price doctrine, a creature of the common law, is being eroded in a common law setting. ${ }^{2}$ Primarily defined by statute, ${ }^{3}$ the status of the holder-in-due-

* Professor of Law, Georgetown University. B.S. 1957, Washington University; J.D. 1961, University of Chicago. The author wishes to express his appreciation to Marc Dorfman, a graduate of the University of Wisconsin Law School, whose research and suggestions contributed substantially to this article.

1. The "time-price doctrine" generally provides that usury laws will not be applied to sales transactions in which the seller quotes one net price for cash sales and another net price for credit sales. See generally Shanks, Practical Problems in the Application of Archaic Usury Statutes, 53 VA. L. Rev. 327 (1967); Comment, Credit Sales at a Price in Excess of the Cash Sale Price as a Violation of the Usury Law, 39 Y ALE L.J. 408 (1930).

2. Hare v. General Contract Purchase Corp., 220 Ark. 601, 249 S.W.2d 973 (1952); Lloyd v. Gutgsell, 175 Neb. 775, 124 N.W.2d 198 (1963); Warren, Regulation of Finance Charges in Retail Installment Sales, 68 Y ALE L.J. 839, 840-51 (1953); Consumer Credit Symposium, 55 Nw. U.L. Rev. 301 (1960). Perhaps the most outspoken critieism of the time-price doctrine appears in R. Speidel, R. Summers, \& J. White, Teaching Materials on Commercial TRANSACTIONS 232 (1969):

Although a trend may be developing against the time price doctrine, a great majority of the states still accept it. Thus in most states if Consumer purehased two TV's, one by agreeing to pay seller a $\$ 400$ time price for a $\$ 200$ TV over 24 months and the other by borrowing $\$ 200$ from a bank for a 24 -month period and agreeing to pay $\$ 200$ of interest on the loan, the former transaction would not violate the usury statute but the latter would. Of course these transactions are functionally identical and the distinctions between them which courts have ostensibly relied on ("People must borrow, but they don't have to buy on time. . . .") are so much hogwash. . . This apparently thoughtless judicial affection for form may reflect a judicial conclusion that lending at a rate greater than the permissible usury rate is necessary and useful.

3. UnIFoRm Commercial CODE $\S \S 3-302$ \& 3-305 [hereinafter cited as UCC]; Uniform Negotiable INSTRUMENTS LAW $\S 52$. 
course has been whittled away, at least in the context of the sale of consumer paper, by both the common law courts ${ }^{4}$ and the legislatures. ${ }^{5}$ The parol evidence rule, also an invention of the common law, has now been codified, at least with respect to "transactions in goods," ${ }^{\circ}$ by section 2-202 of the Uniform Commercial Code. ${ }^{7}$ This article, intended to show that codification has done more to break down the severity of the common law rule than has been realized by either the commentators or the courts, will examine the codification in the context in which the common law parol evidence rule seems to have done the most harm: the typical consumer transaction.

Such a transaction generally follows this pattern: $C$ enters the local appliance store to purchase a color television set. In addition to an effusive description of how the set will perform and what services the seller will provide for the buyer, the salesman makes numerous oral "warranties": "This set is guaranteed against defects for one year; if anything goes wrong, we'll either replace the set or fix it for free"; "This is a brand-new set, never been used"; "This is a wellknown brand; we had to remove the name from this set because of the low price-fair trade laws, you know." Thoroughly persuaded, C purchases the set, signing the omnipresent installment sales contract and detachable negotiable promissory note. The former provides that no warranties, express or implied, have been made other than those that appear in the writing - the "disclaimer" clause-and that the entire agreement of the parties is contained in the contract, and no

4. See, e.g., Commercial Credit Corp. v. Orange County Mach. Works, 34 Cal. 2d 766, 214 P.2d 819 (1950); Mutual Fin. Co. v. Martin, 63 So. $2 d 649$ (Fla. 1953); Unico v. Owen, 50 N.J. 101, 232 A.2d 405 (1967). See generally Jones, Finance Companies as Holders in Due Course of Consumer Paper, 1958 Wash. U.L.Q. 177; Littlefield, Good Faith Purchase of Consumer Paper: The Failure of the Subjective Test, 39 S. CaL. L. Rev. 48, 65-77 (1966); Comment, Judicial and Statutory Limitations on the Rights of a "Holder in Due Course" in Consumer Transactions, II B.C. IND. \& CoM. L. Rev. 90 (1969); Comment, Unico v. Owen: Consumer Finance Companies as Holders in Due Course Under the UCC, 54 VA. L. REv. 279 (1968).

5. Section 2.403 of the Uniform Consumer Credit Code, already enacted into law in Oklahoma, OKLa Stat. Ann. tit. 14A, § 2-403 (Supp. 1969), and Utah, Utah Code ANN. $\S$ 70B-2-403 (Supp. 1969), provides:

In a consumer credit sale . . . the seller . . . may not take a negotiable instrument other than a check as evidence of the obligation of the buyer . . . . A holder is not in good faith if he takes a negotiable instrument with notice that it is issued in violation of this section. . . . U UIform Consumer CRedit CODE $§ 2.403$.

6. "Unless the context otherwise requires, this Article [2] applies to transactions in goods ...."UCC § 2-102.

7. Id. \& 2-202. 
other agreements, warranties or representations exist-the "integration" clause. The salesman may tell C that the contract contains all the terms of the agreement, including the representations and warranties alluded to earlier. Shortly thereafter, the TV set breaks down, and C, trying to get the seller to live up to his "warranties," finds himself in an-irremediable situation. The paper has usually been sold to a finance company which immediately takes refuge in the bastion of holder-in-due-courseship. If the paper has not been sold, and the seller sues for nonpayment, C's defense or counterclaim for breach of contract is hampered by the parol evidence rule when he attempts to introduce evidence of the representations and warranties of the salesman. Either way, $C$ winds up with a judgment against him for the balance of the purchase price of the worthless appliance.

This type of situation has inspired the common law courts' recent trend away from consumer hardship toward help for the victimized buyer. Their decisions have often deprived the finance companies of their "holder in due course" shield and subjected the companies to defenses and set-offs claimed by the buyer ${ }^{8}$ Thus the importance of the changes made in the parol evidence rule by section 2-202 is magnified: not only may defenses be asserted against the seller who carries or has repurchased his own paper; in many cases they may now be asserted against the suing finance company itself. However, winning this first battle against the finance company will be of little use to the consumer if he then founders upon the rocks of the parol evidence rule. Applied with its common law rigor, that rule will prevent the consumer from introducing evidence regarding the conversations preceding the signing of the contract which he thought formed a part of his contract and which supply the foundation for his defenses, counterclaims, and set-offs.

\section{The Parol Evidence Rule and the Common Law}

In establishing the frame of reference in which the Uniform Commercial Code's treatment of the parol evidence rule will be discussed, the following three statements of the rule as it purportedly exists at the common law merit consideration:

When two parties have made a contract and have expressed it in a writing to which they have both assented as the complete and accurate integration of that contract, evidence, whether parol or otherwise, of antecedent understandings

8. See cases cited in note 4 supra. 
and negotiations will not be admitted for the purpose of varying or contradicting the writing.'

When a jural act is embodied in a single memorial, all other utterances of the parties on that topic are legally immaterial for the purpose of determining what are the terms of their act. ${ }^{10}$

[The parol evidence] rule requires, in the absence of fraud, duress, mutual mistake, or something of the kind, the exclusion of extrinsic evidence, oral or written, where the parties have reduced their agreement to an integrated writing."

Obviously these statements of the rule which purport to articulate the same principle vary rather radically. ${ }^{12}$ Since even these leading academic commentators cannot agree about what the rule is, what it purports to exclude, and what evidence may be admitted despite its restrictions, the inconsistencies which appear in the cases are not surprising. As usually applied by the courts, the rule excludes all parol evidence when it is determined that the writing is a "complete integration of the parties' agreement;" 13 if the writing constitutes only a "partial" integration, the rule precludes the introduction of evidence which will contradict in some respect those terms of the parties' agreement which have been reduced to writing. ${ }^{14}$

This article will not discuss at length the common law rule ${ }^{15}$ or the

\footnotetext{
9. 3 A. Corbin, Contracts $\S 573$ (1960) [hereinafter cited as CoRBin].

10. $9 \mathrm{~J}$. WIGMORE, EvIDENCE $§ 2425$ (3d ed. 1940) [hereinafter cited as WIGMORE] (emphasis deleted from original).

II. 4 S. WILLISTON, CoNTraCtS $\S 631$ (3d ed. 1961) [hereinafter cited as WILLISTON].

12. The other widely quoted statement of the parol evidence rule is that of the RESTATEMENT
} of ConTracts $§ 237$ (1932):

[T]he integration of an agreement makes inoperative to add to or vary the agreement all contemporaneous oral agreements relating to the same subject-matter; and also, unless the integration is void, or voidable and avoided, all prior oral or written agreements relating thereto.

Extensive criticism of the Restatement treatment of the parol evidence rule appears in 3 CORBIN $\S 581$ and Sweet, Contract Making and Parol Evidence: Diagnosis and Treatment ofa Sick Rule, 53 CORNELL. L. REv. 1036 (1968).

13. What constitutes a "complete integration" is, of course, a matter of some dispute. One often-used standard has been called the "four-corners" test-"the court will look only within the four corners of the document to determine whether it constitutes a complete expression of the parties' agreement.. . . "Note, The Parol Evidence Rule: Is It Necessary?, 44 N.Y.U.L. REv. $972,973-74$ (1969). Another test is whether "an alleged collateral agreement might "naturally and normally' have been made as separate agreement." Id. at 974. Compare 3 CoRBIN $\S 582$; Sweet, supra note 12, at 1037-38. See also United States v. Clementon Sewerage Authority, 365 F.2d 609 (3d Cir. 1966), which holds that the parol evidence rule is not applieable when the very issue to be determined is whether the writing constitutes an integration. Accord, Atlantic $\mathbf{N}$. Airlines v. Schwimmer, 12 N.J. 293, 96 A.2d 652 (1953).

14. See generally 44 N.Y.U.L. REv., supra note 13, at 973-76.

15. Since numerous commentators have traced the development of the rule, an attempt to do 
development of the numerous exceptions to the rule which are outlined briefly below. A detailed discussion of the effect of section 2-202 on the rule and its exceptions is reserved for subsequent portions of this paper.

Several important exceptions merit brief mention. First, if the court finds that the parties did not intend the writing to be a final integration of the terms of their contract, parol evidence which tends to prove consistent additional terms is admissible. ${ }^{16}$ Second, parol evidence may be admitted to show that no valid agreement was made. ${ }^{17}$ Permitting introduction of testimony relating to such matters as fraud, mistake, or duress, ${ }^{18}$ this exception may also permit proof of oral conditions precedent to the effectiveness of the writing qua contract. ${ }^{19}$ Third, the parol evidence rule permits the showing of failure of consideration. ${ }^{20}$ Fourth, parol evidence is generally admissible to interpret or explain a writing, although some courts maintain that such evidence may be admitted only if the writing is ambiguous and does not have a clear meaning "on its face."21 Finally, the rule only applies to evidence of prior or contemporaneous negotiations which precede the writing and has no effect upon agreements made subsequent to the writing. ${ }^{22}$ While other less important exceptions have developed over the years, those listed above are the most relevant to the consumer situation which constitutes the focus of this paper; subsequent discussions will be limited to exploring the Code's provisions vis-à-vis these exceptions.

so here would be extremely redundant, especially when the article focuses upon section 2-202. For general discussions of the parol evidence rule at the common law, see 3 CoRBIN $\$ 573$ et seq.; 9 Wigmore $\$ 2425$ et seq;; 4 Williston $\$ \S 631-47$; Calamari \& Perillo, $A$ Plea For a Uniform Parol Evidence Rule and Principles of Contract Interpretation, 42 IND. L.J. 333 (1967). See also Associated Hardware Supply Co. v. Big Wheel Distrib. Co., 355 F.2d 114, 119 (3d Cir. 1966):

Where parties, without any fraud or mistake, have deliberately put their engagements in writing, the law declares the writing to be not only the best, but the only evidence of their agrcement: . . . all preliminary negotiations, conversations and verbal agreements are merged in and superseded by the subsequent written contract . . . and unless fraud. accident, or mistake be averred, the writing constitutes the agreement between the parties, and its terms cannot be added to nor subtracted from by parol evidence. (emphasis in original).

16. 3 CoRBin $\S 581 ; 9$ Wigmore $\S 2430 ; 4$ Williston $\S 636$.

17. 3 CoRBin $\S 577 ; 4$ Williston $\S 634$.

18. See Part IV (b)-(d) infra.

19. See Part IV (a) infra.

20. 3 Corbin $\S 586 ; 4$ WiLListon $\S 632$, at $978-82$.

21. 3 Corbin $\$ 579 ; 4$ WILLISTON $\$ 631$, at 973-74.

22. 3 CORBIN $\S 574 ; c f$. UCC $\S 2-209(1)$. 


\section{ThE History OF SECTION 2-202}

In the May, 1949 draft of the Code, section 2-202 provided:

Terms with respect to which the confirmatory memoranda of the parties agree or which are otherwise set forth in a writing intended by the parties as a final expression of their agreement with respect to such terms as are included therein may not be contradicted by evidence of any prior agreement or of a contemporaneous oral agreement but may be explained or supplemented

(a) by course of dealing or usage of trade (Section 1-205) or by course of performance (Section 2-208); and

(b) by evidence of consistent additional terms unless the court finds the writing to have been intended also as a complete and exclusive statement of the terms agreed upon. ${ }^{23}$

Nearly echoing this provision, the present 1962 official draft's only variation is the substitution of the words "of the agreement" for the words "agreed upon" at the end of subsection 2-202(b). This change was suggested by the New York Law Revision Commission "to make it clear that the provision is not limited to express terms." 24

The significance of this change must be evaluated on the basis of an understanding of the definition of "agreement." The 1949 Code defined the term as "the bargain in fact as found in the language of the parties or in course of dealing or usage of trade or course of performance or by implication from other circumstances." 251956 this section was amended to its present form which provides that:

"[A]greement" means the bargain of the parties in fact as found in their language or by implication from other circumstances including course of dealing or usage of trade or course of performance as provided in this Act (Sections 1-205 and 2-208). Whether an agreement has legal consequences is determined by the provisions of this Act, if applicable; otherwise by the law of contracts (Section 1-103) . . . .26

In describing the reasons for the changes, the editorial board merely notes that they "leave the effect of course of dealing and the like to other provisions such as section 1-205."27 The ensuing discussion will show that the matter is not quite that simple.

In suggesting the above changes, the New York Law Revision Commission was apparently coneerned with the potential problems created by a combined reading of sections 1-201(2) and 2-202 of the

23. UCC § 2-202 (May, 1949 Draft).

24. American Law INSTitute, 1956 Recommendations of the Editorial Board for THE UNIFORM COMmerCial CODE 26 [hereinafter cited as 1956 ReCOMmendations].

25. UCC § I-201(2) (May, 1949 Draft).

26. UCC \& 1-201(3).

27. 1956 ReCOMMENDATIONS 13. 
May, 1949 draft. While section 1-201(2) made it quite clear that an "agreement," the "bargain [of the parties] in fact," consisted of both express and implied terms, section 2-202-in using the phrase "terms agreed upon"-may have been interpreted to include only express terms. Thus the "agreement" of the parties would have been something more than the terms .which they had "agreed upon."28 Given that interpretation, a party seeking admission of parol evidence could not introduce additional terms consistent with the express terms of the parties' bargain in fact; he might, however, argue with some merit that he could introduce evidence of additional terms consistent with the implied terms of the bargain in fact even if the writing were the "complete and exclusive statement of the terms agreed upon."

Consider, for example, the well-known case of the exclusive sales agency. ${ }^{29}$ In return for one half of the profits and revenues resulting from Wood's efforts, Lucy, Lady Duff-Gordon, a "creator of fashions," gave Wood the exclusive right to place her indorsements on the designs of others, to place Lucy's own designs on sale, and to license others to market her designs. ${ }^{30}$ When Lucy permitted others to use her indorsements, Wood filed suit, claiming breach of contract. The court rejected Lucy's contention that the writing lacked the "elements of a contract," reasoning that while Wood "does not promise in so many words that he will use reasonable efforts to place the defendant's indorsements and market her designs ... [s]uch a promise is fairly to be implied." 31

28. In fact, the New York Law Revision Commission suggested the following revised text for section 2-202:

1. The terms of a contract for sale as set forth in a writing or writings intended by the parties as a final expression of their agreement with respect to such terms cannot be contradicted by evidence of any other prior or contemporaneous oral or written agreement between the parties. Such final expression may be explained or supplemented by proof of an agreement upon consistent additional terms unless the court finds that such writing or writings constitute a complete and exclusive statement of all of the terms of such agreement. If the additional terms are such that, if agreed upon, they would, as the court finds, ordinarily have been included in the writing or writings, then evidence of such additional terms shall be excluded.

2. Any such final expression may be construed in accordance with Sections 1-205, 2 204, subsection (3) and 2-208. This section does not displace the law of reformation of transactions (Section 1-103). NEw YORK LAW Revision COMMISSION, 1956 RePORT Relating to the Uniform COMmercial CODE 368 [hereinafter cited as N.Y. 1956 REPORT].

The draftsmen of the Code accepted this suggested revision of section 2-202, finding it sufficient to change the last two words of the section.

29. Wood v. Lucy, Lady Duff-Gordon, 222 N.Y. 88,118 N.E. 214 (1917).

30. Id. at 90,118 N.E, at 214.

31. Id. at $90-91,118$ N.E. at 214 . 
Suppose, in the present context, that Lucy defends by alleging that Wood has breached his implied promise to use reasonable efforts to bring about maximum profits and revenues under the written contract. To show the breach, she attempts to adduce evidence that the parties had orally agreed, during the course of their negotiations, that Wood would advertise her products in the New York Times but had instead advertised in a different New York paper which reached a totally different market and probably resulted in substantially lower sales. Under the 1949 formulation of section 2-202, such evidence might have been admitted: although the writing was intended by the parties as the complete and exclusive statement of the terms of the "agreement"- the "express" terms-section 2-202(b) did not operate to prohibit evidence of terms which were consistent with the implied terms of the parties' bargain in fact. Thus, the 1956 change clearly intended to preclude admission of evidence of this alleged oral agreement. ${ }^{32}$

As already indicated, the rewording of section 1-201(3) occurred at the same time as the changes in section 2-202.33 Addition of the

32. The Law Revision Commission may have overlooked the fact that section 1-201 (2) of the May, 1949 Draft included "Agreed" as one of the terms being defined. Thus "terms agreed upon" may have been using the word "agreed" as there defined, eliminating the need for remedial action by the Law Revision Commission.

33. The 1956 revisions made three significant changes in section 1-201(3): the cntire section appearing in the 1949 draft was rearranged and reconstituted as the first sentence of the amended section; the word "Agreed" was deleted from the definition; and the second sentence was addcd. Addition of the third sentence, the only substantive change, results in the admissibility of parol evidence to show, for example, that the parties did not intend their writing to become effective until a condition precedent not set out in the writing had occurred. For a discussion of the New York Law Revision Commission's objections and suggested revisions to the 1949 draft of section 1-201(3), see N.Y. 1956 REPORT 359.

The great significance of the choice of the word "agreement" for use in section 1-201(3) is pointed out in Mooney, Old Kontract Principles and Karl's New Kode: An Essay on the Jurisprudence of our New Commercial Law, 11 VILL. L. Rev. 213 (1966):

[O]ne is struck by the enormous implications of the ostensihly insignificant insistence in the Code on "agreement" rather than "promise." . . Grounding contract on agreement-in-fact, however manifested, the Code wipes out with one sweep the whole figment of promise-for-a-prumise-or-promise-for-an-act. . . . [T] the making of business contracts should be viewed by the law as involving not only the exchange of factual promises or the tendering of unverbalized acquieseence, but, more realistically, as the commeneement of a continuing process of agreement in the broader, more familiar sense. ...

... [A] broader jurisprudential base than promised has been laid for the law of sales .. . but a more noticeable and more important fact is that the seeming multitude of changes in particular traditional rules of contract law gain new significance by refercnce to the Code emphasis on obligation-based-on-agreement-in-fact. Id. at 227-29. 
third sentence, the only substantive change, results in the admissibility of parol evidence to show, for example, that the parties did not intend their writing to become effective until a condition precedent not set out in the writing had occurred..$^{34}$

Strangely enough, changes in the comments to section 2-202 were more significant than the revisions made in the section itself. Although comments 1 and 2 have remained unchanged since the 1950 official draft, comment 3 has undergone substantial revision. ${ }^{35}$ In the text quoted below, the italics represent additions made between 1950 and 1952, and the brackets indicate deletions:

Under paragraph (b) consistent additional terms, not reduced to writing, may be proved unless the court finds that the writing was intended by the parties as a complete and exclusive statement of all the terms. If the additional terms are such that, if agreed upon, they would certainly have been included in the document in the view of the court, then evidence of their alleged making must be kept from the trier of fact. [Before evidence of consistent additional terms becomes inadmissible, both parties must have intended the writing to be a complete and exclusive statement of the terms agreed upon.]

[Either a general clause excluding "all other agreements" when specifically agreed to by both parties or the mere preparation of the agreement on a reasonably fair form can properly be held to evidence an intention to exclude any additional term which, although consistent with the language, is commercially disruptive of the apparent fair intent of the bargain recorded. $]^{38}$

The deletion of the last sentence of the first paragraph of the original comment is perhaps explainable on the ground that it merely restated what was already set out in section 2-202(b) and was thereby excised as redundant. However, it did go somewhat further than the section itself in making clear that the intention specified in section 2-202(b) must be that of both parties; speaking in the passive voice- "intended

34. This sentence recognizes the fact that an agreement may not be legally efficacious or sufficient to constitute a "contract." See Part IV(a) infra. In the May, 1949 draft, section 1201(11) provided that " '[c]ontract' means the total obligation in law which results from the parties' agreement as affected by this Act and any other applicable rules of law." UCC § 1201(11) (May, 1949 Draft). In 1956, the definition was changed to its present form which provides that "contract" means "the total legal obligation which results from the parties' agreement as affected by this Act and any other applicable rules of law. ..." UCC § 1201(11). The change was made "for clarifieation in response to criticism by the New York Commission," 1965 Recommendations 13, which noted the suggestion that "the words "total obligation in law,' in subseetion (11), are inadequate, since 'contract' as used in the Code includes transactions of transfer, such as present sale, and since, in addition, the definition omits any reference to 'conditions,' which may also result from the agreement." N.Y. 1956 REPORT 360.

35. Compare UCC $\S 2-202$, Comment 3 (Proposed Final Draft 1950) with UCC $\S 2-202$, Comment 3 (1952 Official Draft).

36. Comment 3 now appears in a form identical to the 1952 Official Draft. See UCC $\S 2-$ 202, Comment 3. 
also as a complete and exclusive statement"-the section itself may be unclear as to just whose intention it is referring to.

The second paragraph of the 1950 comment seemed to go far beyond the specific language of the section. ${ }^{37}$ First dealing with merger clauses, then with "reasonably fair" forms, the second paragraph seemed to favor the person who was seeking admission of parol evidence. If "both parties" in the typical consumer installment sale transaction very seldom agree about anything,,$^{38}$ and if reasonably fair forms are rare, the draftsmen must have intended this part of Comment 3 to be used in a manner which would overcome the exclusion of parol evidence in the run-of-the-mill consumer form case. Evidence of consistent additional terms would be excluded only if the disclaimer clause were specifically agreed to by both parties or if the parties had signed a reasonably fair form. Furthermore, even if one or both of these two conditions were present, only evidence of a term which was "commercially disruptive of the apparent fair intent of the bargain recorded" would be inadmissible. Just what this latter phrase meant is unclear. In the typical consumer transaction, what sorts of terms would be "commercially disruptive?" Does that phrase refer only to dealings between merchants? How does one demonstrate the "apparent fair intent of the bargain recorded?" Finally, whose "fair intent" is considered-both parties to the transaction, one of the parties, or the reasonable contract-signer?

On balance, inclusion of this paragraph of Comment 3 probably would have been of great use to the consumer attempting to have evidence of consistent additional terms admitted: first, because disclaimers are seldom, if ever, agreed to by both parties; second, because there are few "reasonably fair forms;" and finally, because consistent additional terms usually would not be "disruptive of the apparent fair intent of the bargain recorded." Clearly consumers suffered a disservice by the removal of this part of the comment.

\section{Section 2-202 and the Common law Exceptions}

(a) Oral Conditions Precedent. Historically, the courts have experienced difficulty where the defendant in a breach of contract

37. This practice is a frequent syndrome of the Code comments. See, e.g., E. FARNSworth, Cases and Materials on Commercial Paper 6-9 (1968); R. Speidel, R. Summers, J. White, Teaching Materials on Commercial Transactions 5 (1969). "Perhaps the principal hazard in using the Comments . . . is that they not uncommonly add to or vary the Code language." Id. See generally Skilton, Some Comments on the Comments to the Uniform Commercial Code, 1966 WIS. L. REv. 597.

38. See text accompanying notes $84-89$ infra. 
action alleges that failure of an oral condition precedent precludes effectiveness of the contract being sued on. The principal question in this situation is whether parol evidence of the alleged condition should be admitted.

Evidence that no contract has been formed should be admissible on its own merits, not as an exception to the parol evidence rule. ${ }^{39}$ Moreover, the parol evidence rule is not applicable at common law until the court determines that complete or partial integration exists. ${ }^{40}$ The draftsmen of section 2-202 certainly did not intend to change this result; the possibility that parol evidence would show that the parties never intended a writing to operate as a contract until certain conditions precedent had occurred operates outside the section 2-202 system rather than within it.

The courts, however, have displayed uncertainty concerning this proposition. For example, in Hunt Foods \& Industries, Inc. v. Doliner, ${ }^{41}$ an action for specific performance of a stock option, ${ }^{42}$ the defendant-optionors contended that an alleged oral condition precedent to the effectiveness of the contract had not occurred, precluding any enforceable contract. Denying the plaintiff's motion for summary judgment, the court held that evidence of the oral condition was admissible:

In a sense any oral provision which would prevent the ripening of the obligations of a writing is inconsistent with the writing. But that obviously is

39. "[W]e need not begin excluding parol evidence until we know that a contract has been made." 3 CorBin $\S 577$, at 385. Accord, Bommarito v. Southern Canning Co., 208 F.2d 56 (8th Cir. 1953); Haidinger-Hayes, Inc. v. Marvin Hime \& Co., 206 Cal. App. 2d 46, 23 Cal. Rptr. 455 (1962); Gordy v. Ocean Park, Inc., 218 Md. 52, I45 A.2d 273 (1958).

40. 3 Corbin § 577; Sweet, supra note 12, at 1039. Concluding that the Code makes no attempt to define the criteria by which the courts are to determine whether a complete integration was intended by the parties, most commentators predict that this question will continue to be resolved by the application of pre-Code standards. Calamari \& Perillo, supra note I5, at 344-45; Comment, An Anatomy of Sections 2-20l and 2-202 of the Uniform Commercial Code, 4 B.C. IND. \& CoM. L. REv. 381, 393 (1963). On the other hand, the New York Law Revision Commission thought that section 2-202

insofar as it prescribes that all written memoranda or embodiments of a contract for sale shall be deemed to be partial integrations unless the Court affirmatively finds the writing to have been intended as a total integration is in conflict with an established line of New York cases . . . . The chief purpose of this section is apparently to "loosen up" the parol evidence rule .... New YORK LAW Revision COMMission, STUDY OF THE UNIFORM COMMERCIAL CODE 598 (1955).

41. 26 App. Div. 2d 41, 270 N.Y.S.2d 937, rev'g 49 Misc. 2d 246, 267 N.Y.S.2d 364 (Sup. Ct. 1966).

42. Although the case dcalt with the sale of corporate stock, the court applied section 2-202 because it "applies to article 8 , dealing with securities. . . . All parties and Special Term so regarded it." Id. at 42 n.l, 270 N.Y.S.2d at 939 n.1. 
not the sense in which the word is used . . . . To be inconsistent the term must contradict or negate a term of the writing. A term or condition which has a lesser effect is provable.

....

... We believe the proffered evidence to be inadmissible only where the writing contradicts the existence of the claimed additional term . . . The conversations in this case, some of which are not disputed, and the expectation of all the parties for further negotiations, suggest that the alleged oral condition precedent cannot be precluded as a matter of law or as factually impossible. It is not sufficient that the existence of the condition is implausible. It must be impossible. ....43

In discussing this case, two commentators conclude that, at least with respect to oral conditions precedent, section 2-202 is more restrictive than was the common law parol evidence rule. ${ }^{44}$ However, one of them fears that the effect of the opinion will be quite the opposite of what he thought it was intended to do-that is, by lumping proof of oral conditions precedent in with all other types of "consistent additional terms," the opinion might be interpreted to greatly expand the types of admissible evidence under section 2-202.45 These analyses to the contrary notwithstanding, it is clear that the fears elicited by the Hunt Foods opinion are unfounded under any

43. Id. at 43, 270 N.Y.S.2d at 940 . The Special Term apparently thought that the Code's parol evidence rule with respect to oral conditions precedent was stricter than that of the common law. The court acknowledged that "[a]n exception [to the parol evidence rule] is made when the object is to prove that a writing, apparently valid and complete on its face, was not to become effective unless and until the occurrence of an orally agreed upon condition precedent," thereby demonstrating that "no contract ever came into existence." However, the Speeial Term reasoned, that exception was not applieable under section 2-202, at least in the case under consideration, "since the record compels a finding that the writing sought to be implemented is 'a complete and exclusive statement of the terms of the agreement.' " 49 Misc. 2d 246, 247, 249, 267 N.Y.S.2d 364, 367, 368 (Sup. Ct. 1966).

44. Comment, Contracts-Parol Evidence-“Consistent Additional Terms" Within Section 2-202(b) of the Uniform Commercial Code, 12 N.Y.L.F. 520 (1966); 66 Colum. L. Rev. 1370 (1966).

45. If the court had made clear that this test [factual impossibility] was to be applied only in the case of summary judgment, its decision would represent the proper application of summary judgment rules to parol evidence issues. However, its opinion ... can be read to extend to motions for exclusion of evidence as wcll. General application of an "impossibility" standard would severely impair the utility of the parol evidence rule. When the court is faced with a motion to exclude the evidence at trial, it must decide whether the parties in fact intended the term to be part of their final agreement, not merely whether the existence of sueh an intent is possible. The court's failure to discuss the consequences of an "impossibility" standard suggests that it did not intend to set forth a sweeping rule. . . It should not . . . be supposed that an "impossibility" test has any relevance in the usual parol evidence case. 66 CoLum. $L$. REV. 1370, 1376 (1966). 
proper interpretation of section 2-202. First, even if that section is applicable at all, the Hunt Foods court was in fact dealing with a rather narrow legal issue: admission of evidence which would tend to prove the existence of an oral condition precedent to the effectiveness of the contract. ${ }^{46}$ Second, if section $2-202$ is not germane in such a case at all, the implications of Hunt Foods are, of course, substantially diminished.

Dealing with Hunt Foods on its own terms, one very difficult question immediately arises: $1 \mathrm{~s}$ it really possible to say that a term or condition which negates the existence of a contract itself can ever have a "lesser effect" than one which contradicts or negates a single term of the contract? In a very real sense, a parol condition precedent contradicts the very essence of the writing -its existence as a contract. Contradicting only one term of a writing must of necessity be a lesser evil. Nevertheless, Hunt Foods indicates that evidence that no contract ever existed is subject to the parol evidence rule, despite commentators' sanguine statements to the contrary. ${ }^{47}$

In Hicks v. Bush, ${ }^{48}$ a case upon which the Hunt Foods court placed heavy reliance, the parties entered into a contract for the merger of their various corporate interests into a holding company.

46. The mischief inherent in the Hunt Foods treatment of oral conditions precedent manifested itself in the more recent case of Whirlpool Corp. v. Regis Leasing Corp., 29 App. Div. 2d 395, 288 N.Y.S.2d 337 (1968). In Whirlpool, the defendant issued a purchase order to the plaintiff for certain equipment, In answer to the plaintiff's subsequent action for breach of contract, the defendant alleged that prior to the issuance of the purchase order, the plaintiff had orally agrced to supervise the installation of the equipment and perform other related tasks before the defendant incurred any obligation to pay for the goods. Despite the fact that Whirlpool appears to be a run-of-the-mill parol evidence case involving two parties clearly bound by a contract (whatever its terms may in fact be), the court for some reason felt constrained to resolve the dispute under Hunt Foods:

While generally an integrated written agreement may be shown not to have taken effect beeause of an oral condition precedent, this being an exception to the parol evidence rule, the exception does not apply where the oral condition precedent would contradict the express terms of the writing. . . . [T]his legal principle has been incorporated into the statute (Uniform Commercial Code $\S 2-202$ ). Id. at 397, 288 N.Y.S.2d at 339.

The court then excluded the proffered evidence on two grounds: first, the evidence would contradict the provisions of the writing relating to discount and payment; second, this sort of term, contemplated by Comment 3 to section 2-202, would ordinarily be contained in the writing. Although the dissent thought that the term was not contradictory to or inconsistent with the writing, it also treated the case as one which involved a condition precedent. Id. at 399-400, 288 N.Y.S.2d at 341.

47. "The parol evidence rule is predicated upon the assumption that the parties have entered into a valid agreement; a party is always permitted to show that no valid agreement was made." Sweet, supra note 12 , at 1039.

48. 10 N.Y.2d 488, 180 N.E.2d 425, 225 N.Y.S.2d 34 (1962). 
Each party agreed to subscribe for a certain number of shares in the new company, the subscriptions to be made within five days of the agreement. In response to plaintiff's suit for specific performance, the defendant asserted that the agreement "was not to operate" as a contract until occurrence of an alleged parol condition - the raising of "equity expansion funds" in excess of $\$ 650,000$. The court permitted evidence of the alleged parol condition, setting forth the following test for determining the admissibility of such evidence:

Parol testimony is admissible to prove a condition precedent to the legal effectiveness of a written agreement if the condition does not contradict the express terms of the written agreement. A certain disparity is inevitable, of course, whenever a written promise is, by oral agreement of the parties, made conditional upon an event not expressed in the writing. Quite obviously, though, the parol evidence rule does not bar proof of every orally established condition precedent, but only of those which in a real sense contradict the terms of the written agreement. 40

Because the parol agreement in Hicks dealt with a matter upon which the writing was silent, the court determined that the testimony did not contradict the terms of the agreement and that it was, therefore, admissible. This reasoning is, of course, pure sophistry. Evidence of an oral condition precedent contradicts every clause in the writing, for it is used to show that what appears on its face to be a binding contract is in fact nothing more than a piece of paper with some printing on it, never intended by the parties to have legal efficacy until some event, unspecified in the writing, has occurred. Thus, the problem is to determine whether the language of section 2-202 will support an argument that conditions precedent are without its ambit of operation..$^{50}$

As Professor Corbin points out, the situation presented in Hicks $v$. Bush may be viewed in two ways. Either "the written instrument was not to become a valid contract prior to the procuring of the funds, or ... the obligations of the parties under an irrevocable written instrument were to be conditional on the procurement of the funds." If the former is found to be true, he reasons, parol evidence is always admissible, whether it is contradictory to the writing or not. He rejects the numerous cases which deal with the issue on the latter supposition

49. Id. at 491,180 N.E. $2 \mathrm{~d}$ at 427,225 N.Y.S.2d at 36 (citations omitted).

50. The most common situation in which the consumer might try to prove that no contract had ever been entered into is where the seller agrees with the buyer that their writing will not be effective unless the buyer can obtain his own financing.

51. 3 Corbin $\S 589$, at 274 (Supp. 1964). 
and refuse to admit such evidence, charging that these cases are erroneous and should "be disapproved as based upon ancient notions as to paper writings ...."52 Acknowledging that "the actual intention of the parties, as between the two alternatives discussed above, may be difficult or even impossible to ascertain," he counters that the question of intent "should be wholly immaterial if the court can hold ... that the oral provision is truly supplementary to the writing and not contradictory to it." ${ }^{.53}$ In fact, the court in Hicks $v$. Bush determined that the parties desired and intended the merger "to be one of proposal only and that, even though the formal preliminary steps were to be taken, the writing was not to become operative as a contract or the merger effective until $\$ 652,500$ was raised." 54 By its own view of the evidence, the court could then have taken the position that the parol evidence rule did not apply at all, because there was in existence no contract with which the evidence proffered could be consistent or inconsistent. Perhaps the court is really saying that the evidence is believable and that credibility, not admissibility, is the crux of the case. ${ }^{55}$

Be that as it may, some courts still fail to recognize Corbin's two distinct interpretations-either that no contract exists at all, or that the existing contract is subject to a condition precedent. Consequently, these courts never reach the question of whether the same standards of admissibility should be applied to each interpretation. Indeed, Hunt Foods exhibits this confusion and will hardly provide a beneficial rationale to the consumer's attorney in

52. Id. at 275 .

53. Id. In analyzing a particular case, Professor Corbin suggests that . . . we should ask the following questions: (1) Was the transaction revocable? (2) In order to make a contract was a new expression of assent necessary? (3) If the event, orally stated as a condition, occurred would the agreement be enforceable despite supervening deaths and revocations? In most of the cases . . . questions (I) and (2) would be answered No, and question (3) would be answered Yes, showing clearly that a valid contract was made; and yet parol evidence was admitted to prove that a party's legal duty was conditional and its admission based upon sound judicial instinct as to the requirements of justice. 3 CORBIN $\S 589$, at 545 .

54. 10 N.Y.2d at 493,180 N.E.2d at 428,225 N.Y.S.2d at 38.

55. See Note, A Critique of the Parol Evidence Rule in Pennsylvania, 100 U. PA. L. Rev. 703 (I952):

[A]ll evidence will be considered, but, in order to satisfy the burden of proof imposed upon the proponent of the oral agreement, the necessary quantum and quality of his evidence will vary directly with the improbability of his contention. This evidence need not be believed merely because it must be considered. Id. at 72 I (emphasis omitted). 
any case in which a parol condition precedent is pleaded. ${ }^{58}$ It is certainly riskier to operate within the ambit of the parol evidence rule, however confident one may be about the outcome, than to operate outside its scope entirely where there will be no question of the admissibility of the evidence. ${ }^{57}$

Turning specifically to the precise language of section $2-202$, it should not be ovcrly difficult to conclude that evidence that the parties did not intend the writing to be legally binding should be admitted. Section 2-202 states that "prior agreement[s]," "contemporaneous oral agreement[s]," and "consistent additional terms" are inadmissible, the latter terms being inadmissible only where the writing is intended to be "a complete and exclusive statement of the terms of the agreement." Section 1-201(3) recognizes two types of "agreements": those which have "legal consequences" and those which do not. That section further directs us to look either to other sections of the Code or to general contract law in order to determine whether or not the agreement does in fact have legal consequences. Since there are no provisions in the Code dealing with conditions precedent to the effectiveness of an agreement, one perforce must look to the common law of contracts, not section $2-202$, to determine whether the agreement does in fact have any legal consequences. And since we are not then operating under section 2-202, no impediment blocks the introduction of evidence of parol conditions precedent. Thus, in Corbin's terms, parol evidence is admissible to show that

56. The problems raised by Hunt Foods are discussed at length in R. DuesenBerg \& L.

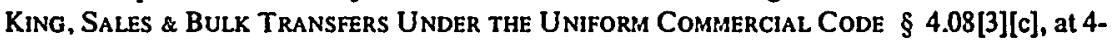
135 n.73 (1969), where the authors opine that Hunt Foods

should not be taken as giving license to a court to hear evidence of any and all terms alleged to be part of a transaction evidenced by writing. Notice that the term asserted in that case was in addition to those set out in writing, and was in no way necessarily contradictory to the written terms. If the asserted oral term is contradietory, and does not fall within the exceptions to the parol evidence rule (such as contradictory course of performance), then evidence of the term should not be admitted.

Moreover, the authors point out that the language of the opinion would make the impact of section 2-202 "enormous, since it is difficult to conceive of any agreement to which some additional term might not have been added and which is not necessarily inconsistent." Id. at 4138 n.74.I. A similar "Pandora's box" argument appears in note 45 supra. Such a parade of horrible postulates is unappealing: first, because these predictions rarely come true; and, second, because these cases deal only with one rather discrete category of contract problems.

57. Compare Gem Corrugated Box Corp. v. National Kraft Container Corp., 427 F.2d 449, 502-03 (2d Cir. 1970).

For a discussion of the general problem of counseling clients about the probable outcome of cases involving the parol evidence rule, see Sweet, supra note 12, at 1044-45. See also Regnan, Parol Evidence-The Utah Version, 5 UTAH L. Rfv. 158, 168-69 (1956). 
"the written instrument was not to become a valid contract" prior to the occurrence of the condition specified in the parties' extraneous oral agreement. Crucial to this determination, of course, is the proposition that the "agreement" mentioned in section 2-202 refers only to agreements which have legal consequences. The history of the section would appear to make that clear. Indeed, to hold otherwise would be circular reasoning at its most vicious: to determine whether or not an agreement was intended to have legal efficacy requires parol evidence; but parol evidence will be excluded on the assumption that all written agreements are intended to have legal efficacy. Flying in the face of section 1-201(3), a conclusion that section 2-202 bars the introduction of evidence which would show that the parties never intended that their writing have legal consequences is contrary to a substantial body of legal precedent and commentary. ${ }^{58}$

The relationship between oral conditions precedent and the parol evidence rule is complicated still further by the ubiquitous integration clause. For example, in "Luther Williams, Jr., Inc. v. Johnson, ${ }^{59}$ a contract for home improvements ${ }^{80}$ provided that the writing "emb odies the entire understanding between the parties, and there are no verbal agreements or representations in connection therewith." In plaintiff's suit to recover liquidated damages pursuant to a covenant contained in the writing, the court permitted the defendant to introduce evidence that the effectiveness of the contract for improvements depended upon the defendant's ability to obtain financing from his bank and that both parties understood that the defendant would not become obligated under the contract until he procured the funds. The court's own words provide an explicit statement of the issue at hand: "[C]an it be said that the testimony regarding the condition precedent does not contradict the writing

58. For example, in the analogous situation of interpreting an absolute deed intended as a mortgage, parol evidence is always admitted to show that what appears on its face to be a final conveyance of real estate was really intended as security only. Beeler v. American Trust Co., 24 Cal. 2d 1, 147 P.2d 583 (1944); Pierce v. Robinson, 13 Cal. 116 (1859); Umpqua Forest Indus. v. Neenah-Oregon Land Co., 188 Ore. 605, 217 P.2d 219 (1950); 3 CoRBIN $\& 587$, at 507; G. OSBORNE, HandBoOK ON THE LAw OF MoRTGages $\$ \S 75-78$ ( $2 \mathrm{~d}$ ed. 1970). While analogies to the chancellor's fervent desire to protect the equity of redemption may be risky, one should nevertheless realize that the consumer is increasingly becoming just as big a favorite as mortgagors, widows, and orphans.

59. 229 A.2d 163 (D.C. Ct. App. 1967).

60. Since it applies only to "transactions in goods," article 2 is thus inapplicable in the Williams case. See UCC § 2-102(1).

61. 229 A.2d at 165 . 
when the contract states there are no agreements other than those contained in the writing?" 62

Although the court was cognizant of a substantial body of authority holding to the contrary ${ }^{63}$ it answered the question in the affirmative, concluding that the contrary decisions were founded upon an erroneous interpretation of section 241 of the Restatement of Contracts. ${ }^{64}$ That section, the court reasoned, does not intend the automatic exclusion of parol evidence in the presence of an integration clause, but contemplates exclusion "only if the alleged parol condition contradicts some other specific term of the written agreement." ${ }^{15}$ Since the writing contained no reference to financing, the defendant's testimony concerning the oral agreement did not contradict any of the writing's terms and was admissible. The court's opinion left unexplored the remaining area of operation of integration clauses.

As in Hunt Foods and Hicks v. Bush, the court in Williams chose to operate within the perimeters of the parol evidence rule, rather than holding that the parol evidence rule has no applicability with respect to this question. ${ }^{66}$ The problems with this sort of reasoning are obvious; ${ }^{67}$ however, Williams does seem to indicate that whatever the ultimate rationale adopted by cases such as Hunt Foods which were decided under the Code, the presence of an integration clause should

62. Id.

63. Id. at 166 (citing Rowe v. Shehyn, 192 F. Supp. 428 (D.D.C. 1961)); J \& J Constr. Co. v. Mayernik, 241 Ore. 537, 407 P.2d 625 (1965).

64. Where parties to a writing which purports to be an integration of a contract between them orally agree, before or contemporaneously with the making of the writing, that it shall not become binding until a future day or until the happening of a future event, the oral agreement is operative if there is nothing in the writing inconsistent therewith. RESTATEMENT OF CONTRACTS $§ 241$ (1932).

65. 229 A.2d at 166 .

66. The presence of an integration clause, according to Professor Corbin, "does not prove that the document itself was ever assented to or ever became operative as a contract." 3 CorBin $\S 578$, at 405 . Compare the following:

The distinction (of $\S 2-202$ ) between a parol (unintegrated) agreement which "contradicts" one or more terms of the writing and one which is used to "explain or supplement" its terms may be difficult to maintain in practice; and its uncertainty tends to impair the policy of protecting the effectiveness of a written instrument. However, the New York courts have already accepted this distinction in accepting the concept of partial integration. Whether this concept will succumb to the usual "merger clause" . . . in formal sales contracts is not settled in New York, but an affirmative answer seems likely. New York Law Revision Commission, Study of Uniform Commercial. Code 601 (1955).

67. See notes $46-49$ supra and accompanying text. 
not bar the result reached-the admission of parol evidence of a condition precedent.

(b) Fraud. At common law, parol evidence is generally admissible to prove fraud. ${ }^{68}$ While section 2-202 makes no direct mention of fraud, it is doubtful that the Code has effected any changes in this area.

In Associated Hardware Supply Co. v. Big Wheel Distributing Co. ${ }^{69}$ the plaintiff seller sued for the unpaid balance of an account. The defendant buyer counterclaimed, alleging that his signature was obtained by the seller's material misrepresentations which amounted to fraud in the inducement. Rejecting the seller's contention that section 2-202 contained no exception allowing parol evidence of fraud, the court concluded that section 1-103 carried the common law exception for fraud into section 2-202..$^{70}$ Nothing in the Code or the cases would appear to be contradictory to this conclusion.

(c) Misrepresentation. Although the term "misrepresentation" is not generally found in lists of exceptions to the parol evidence rule, evidence of material misrepresentation has been admitted occasionally to contradict a written contract. ${ }^{71}$ For example, in HullDobbs, Inc. v. Mallicoat, ${ }^{72}$ an automobile dealer sought to invoke

68. See text accompanying note 18 supra.

69. 355 F.2d 114 (3d Cir. 1965).

70. Id. at 119. Cf. Sweet, Promissory Fraud and the Parol Evidence Rule, 49 CALIF. L. REv. 877 (1961). Some support for the proposition advanced in Associated Hardware is presented in Toker v. Perl, 108 N.J. Super. 129, 260 A.2d 244 (App. Div. 1970), affg 103 N.J. Super. 500, 247 A.2d 701 (Law Div. 1968), and Symonds v. Adler Restaurant Equip. Co., 6 UCC Rep. SERv. 808 (Okla. 1969). With respect to evidence of fraud, illegality, mistake, or accident in general, Professor Corbin initially stated that "oral testimony is admissible to prove fraud, illegality, accident or mistake. This is so, even though the testimony contradicts the terms of a complete integration in writing." 3 Corbin $\$ 580$, at 431 . Professor Sweet, after reviewing the leading California cases on promissory fraud, noted the fact that many cases refuse to admit evidence of oral promises, despite allegations that they were made without any intention on the part of the promisor to perform, "if the alleged oral promise is at variance with the writing." Demonstrating that the Restatement of Contracts $\S 238$ (1932), disagrees with the California formulation, he suggested that Professor Corbin, "perhaps overenthusiastically, denies any effeet to inconsistency." Sweet, supra, at 879-80. 1n a later supplement to his work, Professor Corbin acceded to this charge and acknowledged that Professor Sweet's statement was correct. 3 Corbin $§ 580$, at 228 (Supp. 1964).

71. The narrow distinction between fraud and misrepresentation of a material fact is blurred by the courts" frequent combinination of these terms into some form such as "fraudulent representations." See, e.g., Wachtman v. Derran Food Plan, 71 Dauph. 121, 130 (Dauph. County Ct., Pa. 1957) ("Misrepresentations made under the circumstances aforementioned are fraudulent and are implied, constructive or legal fraud or fraud in equity.").

72. 57 Tenn. App. 100, 415 S.W.2d 344 (1966). 
section 2-202 to exclude parol evidence of representations concerning the condition of the car which he had sold. The writing in question, entitled "Security Agreement," contained an integration clause and a statement that "warranties, representations and promises" were not to be binding on any assignee of the seller. In holding the evidence admissible, the court stated:

Since the "agreement" and "representations, warranties and promises" are treated as being separate and distinct and representations as to the condition of property sold are not generally considered a part of the agreement but an inducement to the execution of the sale agreement, we can not say the parties intended the Security Agreement to be a final statement of the terms of the sale. Representations as to the condition of the car are not inconsistent with any provision of the contract even if it should be held that the Security Agreement was intended as a final statement of the terms of the sale. ${ }^{73}$

The italicized portion of the quotation makes it clear that the court was perfectly prepared to admit the evidence-contradictory though it may have been-on section 1-103 grounds and not as an exception to section 2-202.

The consumer's attorney in the misrepresentation situation, therefore, may first try the avenue of fraud in order to avoid application of section 2-202, or, failing to convince a court which is applying a very stringent definition of fraud, he may always try to have the court adopt a theory that evidence of false representations is also an exception to the Code's parol evidence rule.

(d) Mistake. Most discussions of the common law parol evidence rule lump together fraud, accident, and mistake as generally recognized exceptions. ${ }^{74}$ As was true in the case of fraud, the interpretations of section 2-202, although hardly plentiful, seem to indicate that parol evidence of mistake will be admitted.

The case most specifically in point is General Equipment Manufacturers $v$. Bible Press, Inc. ${ }^{75}$ In that case, the defendant entered into a contract with the Archdiocese of Detroit to install equipment in its schools and asked plaintiff, the defendant's supplier, to provide a quotation for the equipment involved. The plaintiff's response stated a quotation of $\$ 32,000$ which included cost, freight, and installation charges for each item. Defendant thereupon sent a purchase order to plaintiff for "[o]ne lot of laboratory furniture per

73. Id. at 104, 415 S.W.2d at 346 (emphasis added). Accord, Culp v. Bloss, 203 Kans. 714, 457 P.2d 154 (1969) (pre-Code).

74. See, e.g., 3 CoRBIN $\$ 580 ; 4$ WILLISTON $\S 634$.

75. 10 Mich. App. 676, 160 N.W.2d 370 (1968). 
quote of [plaintiff] ...." Around the time for delivery and installation ten or eleven months later the plaintiff sent a letter, dated July 19 , to the defendant, stating inter alia that the charges were the amount quoted in the original order but failing to include $\$ 3,000$ for installation charges. Upon completion of the order, the Archdiocese made payment by check payable to plaintiff and defendant jointly. The plaintiff ultimately remitted to defendant the difference between the amount of the check and the amount quoted in the plaintiff's July 19 letter, resulting in an overpayment to defendant of a little over $\$ 2,600$. When defendant refused to refund that amount, this suit ' followed.

Since the trial court below was unsure whether the purchase order or the letter of July 19 constituted the final contract of the parties, it admitted evidence of all the negotiations between the parties and held for the plaintiff. In affirming the admission of parol evidence to show unilateral mistake, the appellate court found that the plaintiff should be permitted to recover upon a theory of unjust enrichment, since the defendant showed no detrimental reliance upon the overpayment. While it did not specifically determine which was the "real" contract between the parties, the appellate court clearly would have reached the same result regardless of the final determination of this question. Thus, parol evidence would be admissible in a case of unilateral mistake, a conclusion which seems to be based upon section 1-103.

(e) Subsequent Agreements. Although section 2-202 limits the admission of "evidence of any prior agreement or of a contemporaneous oral agreement" to contradict the terms of a written agreement, ${ }^{78}$ the section does not prevent proof of an agreement made after the writing was entered into, even if the new agreement contradicts or varies the terms of the previous agreement. The parol evidence rule was not designed to prevent the introduction of evidence showing that the parties have changed their minds. ${ }^{77}$

This "exception" to the parol evidence rule can be a valuable tool to the consumer's lawyer. If, for example, the client contacts his lawyer soon enough after the transaction, it may be possible to "create" evidence which no rule purports to render inadmissible. If the client returns to the seller, accompanied by witnesses, and

76. UCC § 2-202.

77. Section 2-209(1) carries this principle further by providing that "[a]n agreement modifying a contract within this Article needs no consideration to be binding." UCC § 2 209(1). 
complains about his purchase, the seller may seek to pacify the client by making additional express warranties or other promises. These new warranties may easily be considered part of the "basis of the bargain" identified in section $2-313,{ }^{78}$ because they are intended by the seller to make the buyer content with his merchandise. Comment 7 to section 2-313 strenghtens this conclusion:

The precise time when the words of description or affirmation are made . . . is not material. The sole question is whether the language . . . [is] fairly to be regarded as part of the contract. If language is used after the closing of the deal . . . the warranty becomes a modification . . . . 70

The seller, on the other hand, may feel that he is completely protected and need not pacify his customer. $\ln$ this case he may make some damaging admission about the goods along with his summary dismissal of the buyer. Such an admission about the goods can be evidence of a lack of good faith, which is obligatory in every contract or duty within the Code and goes both to performance and enforcement. ${ }^{80}$

In summary, many courts hold that the eommon law still applies in determining the applicability of the common law exceptions to the parol evidence rule under section 2-202, concluding that section 2-202 is determinative only when the parties have actually entered into a legally efficacious contract.

\section{Section 2-202: Legislative Intent AND JUDICIAL INTERPRETATION}

Inherent in the foregoing discussion is the contention that section 2-202 diverges from the common law incantations of the parol evidence rule. But how different is it? To what extent has the common law rule been changed?

78. "Any affirmation of fact or promise made by the seller to the buyer which relates to the goods and becomes part of the basis of the bargain creates an express warranty that the goods shall conform to the affirmation or promise." UCC $\S 2-313(1)(a)$.

79. Id., Comment 7.

80. UCC § 1-203. See generally Summers, "Good Faith" in General Contract Law and the Sales Provisions of the Uniform Commercial Code, 54 VA. L. REv. 195 (1968).

81. General discussions of the changes wrought by section 2-202 on the law of individual states may be found in Bigham, Tennessee Law and the Sales Article of the Uniform Commercial Code, 17 VAND. L. REv.873, 881-82 (1964); Davenport, The Nebraska Uniform Commercial Code: An Introduction and Articles $I$ and 2, 43 NEB. L. REV. 671, 694-95 (1964); McDonough, The Parol Evidence Rule in South Dakota and the Effect of Section 2-202 of the Uniform Commercial Code, 10 S.D.L. REv. 60 (1965); Comment, Unsettling the SettledThe Uniform Commercial Code and the Law of Contracts, 14 KaNs. L. REV. 509, 514-15 
The New York Law Revision Commission, commenting upon the section prior to the change made in the $1957 \mathrm{draft}$, suggested that

insofar as [section 2-202] prescribes that all written memoranda or embodiments of a contract for sale shall be deemed to be partial integrations unless the Court affirmatively finds the writing to have been intended as a total integration, [it] is in conflict with an established line of New York cases . . . . The chief purpose of this section is apparently to "loosen up" the parol evidence rule by abolishing the presumption that a writing (apparently complete) is a total integration, "a complete and exclusive statement of the terms agreed upon," and by requiring the court to make a definite finding that the parties intended a total integration before "consistent additional terms" (parol) are to be excluded . . . . 82

It is apparent that section 2-202 went even further in changing the law than the New York Law Revision Commission thought it did. Perhaps the most interesting case in support of this proposition is one which at first reading does not seem to involve section 2-202 at all, since the transaction with which it was concerned probably occurred prior to the Code's effective date. However, while never directly mentioning section 2-202, the court invokes its substance in important portions of its opinion, leading to the conclusion that that section did indeed govern the result in the case. More specifically, in Ciunci $v$. Wella Corp.$^{83}$ the plaintiff signed the following printed agreement:

In consideration of giving me a permanent wave and/or . . . any other service free of charge, I hereby release . . . the Wella Corporation . . . from (1) any and all liability for any damages and/or injuries resulting from or caused by the technicians and/or equipment, accessories, lotions, creams and/or treatment used in connection therewith and (2) from any and all liability for damage and/or injury sustained by me as a result of using any products purchased by me from you which are sold by the Wella Corporation. Any products purchased by the undersigned from you shall not be deemed to be whole or part consideration for the foregoing release. ${ }^{44}$

When plaintiff's ear was injured during the hair treatment she brought this action against the corporation..$^{85}$ During the trial the

(1966); Comment, The Mechanics of Parol Modification of Contracts Under the Uniform Commercial Code, 29 U. PITT. L. Rev. 665 (1968).

The relationship of parol evidence and article 3 of the Code is discussed in Peters, Suretyship Under Article 3 of the Uniform Commercial Code, 77 Yale LJ. 833, 848-61 (1968).

82. New YoRK LAW Revision COMmission, supra note 66, at 598-601.

83. 26 App. Div. 2d 109, 271 N.Y.S.2d 317 (1966). Other commentators have also concluded that section 2-202 was held applicable in this case. See R. DuesenBerg \& L. KING, supra note 56 , at 4-134 n.72.1.

84. 26 App. Div. $2 d$ at $110-11,271$ N.Y.S.2d at 318 .

85. The theory of the action is not set out. 
parties stipulated that the plaintiff, if called to the stand, would testify that at the time she signed the above agreement, an employee of the defendant told her that the agreement was for the purpose of relieving the defendant from responsibility for injury to her hair; they further stipulated that defendant's manager, if called to testify, would state that he had no knowledge of any conversation with the plaintiff regarding the meaning or intent of the agreement.

In reversing the trial court's entry of judgment in favor of the defendant, the appellate court stated that

the issue to be determined was whether the covenant not to sue is broad enough to prevent recovery for injury to the ear, as well as to the hair. The parties disagree on that. That issue cannot be determined solcly on the basis of the card signed by the plaintiff for the card does not point to the answer. Accordingly, the intent of the parties must be aseertained from testimony. Such testimony would be admissible, for it would not contradict the writing, but would be evidence of a consistent additional term to the writing.

The contract in Ciunci, although harsh and one-sided, states in rather plain and understandable terms that the defendant is not liable for any damage or injury to the plaintiff. However, it seems clear that the court thought it unconscionable to permit the defendant to absolve itself from all responsibility for injury to the plaintiff just because she received a free hair treatment. While it could have brought notions of public policy into play, resulting in a declaration that the contract was void, ${ }^{87}$ the court apparently thought it could compel the same result within the framework of the parol evidence rule.

The court's rationale presents two justifications for its circumvention of the parol evidence rule. First, "the intent of the parties must be ascertained from testimony." The court must have thought it possible, therefore, that the parties in this case intended to agree to different things. Reasoning that "intent" is a factual question and cannot be determined solely by referenee to any writing, the opinion implies that parol testimony must be received to resolve the point.

The second aspect of the court's rationale is that evidence of intent is admissible as evidence of a "consistent additional term." Obviously, however, proof of an intent different from that evidenced by the writing is proof neither of a consistent term nor of an

86. Id. at 111,271 N.Y.S.2d at 319.

87. Cf. Williams v. Walker-Thomas Furniture Co., 350 F.2d 445 (D.C. Cir. 1965); Henningsen v. Bloomfield Mọtors, Inc., 32 N.J. 358, 161 A.2d 69 (1960). 
additional term. Rather, it is proof of an inconsistent alternative term. . $^{88}$

The importance of this case can be clearly demonstrated only if it is brought into focus in a section 2-202 context. Speaking in the plural, the section says "the parties" agree," "intended by the parties," and "their agreement." Thus, the first requirement of this section is that a writing, to be protected from the introduction of parol evidence, must be the agreement of both parties. The comments also indicate the draftsmen's desire to have the courts discover and enforce expectations of the parties, rather than binding the parties to an agreement which one of them may never have contemplated. Of particular importance is Comment 3 which provides, in the context of subparagraph $b$, that "consistent additional terms ... may be proved unless the court finds that the writing was intended by both parties as a complete and exclusive statement of all of the terms." 89 Surely what is true with respect to the draftsmen's interpretation of section 2-202(b), which speaks in the passive voice, is also true with regard to section 2-202's earlier uses of the plural form in the statute itself..$^{90}$

The contract of adhesion is something with which all consumers and their attorneys are familiar. ${ }^{91}$ Written by one party, the seller in

88. After all, the agreement did provide for the release of the defendant from "any and all liability for any damages and/or injuries . . . ." If the case were to go to trial again, and the plaintiff were permitted to introduce evidence of her understanding of the contract, the resulting agreement would be treated as if it had read "any and all liability for any damages and/or injuries resulting to my hair . . . This is hardly what the defendant contemplated, either at the time it drafted the agreement or when it presented the agreement to the plaintiff for her signature.

89. UCC $\$ 2-202$, Comment 3.

90. But cf. Palmer, Reformation and the Parol Evidence Rule, $65 \mathrm{MicH}$. L. Rev. 833 (1967):

It is debatable whether the language ["intended by the parties as a final expression of their agreement with respect to" the terms that are in question] is meant to permit direct contradiction of a written term which the parties did not intend to be an accurate expression of their actual agreement. . . . If the propriety of such a contradiction was contemplated it would have been better to provide: "intended by the parties as a final and accurate expression etc." Id. at 835 n.8.

91. See generally Hale, Bargaining. Duress, and Economic Liberty, 43 Colum. L. Rev. 603 (1943); Kessler, Contracts of Adhesion-Some Thoughts About Freedom of Contract, 43 Colum. L. Rev. 629 (1943); Meyer, Contracts of Adhesion and the Doctrine of Fundamental Breach, 50 VA. L. REV. 1178 (1964).

In the context of the automobile sales contract, the court in Henningsen v. Bloomfield Motors, Inc., 32 N.J. 358, 390, 161 A.2d 69 (1960), noted that "[t]he warranty before us is a standardized form designed for mass use. It is imposed upon the automobile consumer. He takes it or leaves it, and he must take it to buy an automobile. No bargaining is engaged in with 
the consumer transaction, the adhesion contract is couched in highly technical language which is often mysterious even to the well-educated consumer; to the less-educated consumer, it may be entircly incomprehensible. Since the buyer must sign the contract of adhesion without any possibility of altering its terms or conditions, his only choice is to buy under the stated conditions or not to buy at all. When the item covered by the contract is a necessity, or at least very important to the consumer's own view of his life-style, the consumer has no choice at all since he is not free to adopt the latter alternative of not buying. Finally, the consumer's problem is aggravated when every dealer uses similar or identical forms.

The only prerequisite to the common law parol evidence rule's most rigorous application was an intention by both parties to enter into a contract..$^{92}$ Thus, if the consumer admitted upon crossexamination that, yes, he knew he was signing a contract-albeit he did not know what the terms were-and, yes, he intended to enter into a contract with the seller, the parol evidence rule blocked all further attempts to introduce parol evidence of intent. Section 2-202, on the other hand, contemplates that no "bargain of the parties in fact," and thus no "agreement," can exist in the absence of concrete knowledge by the buyer regarding all the terms of the contract which he is signing. Thus, if both parties must intend the terms of the writing to be the final expression of their agreement in order for section 2-202 to apply, both parties must know and understand what was in the contract. In most situations, it is unlikely that the buyer will understand the terms of the writing even if he could and did read them..$^{93}$ Moreover, a party cannot intend something which he doesn't understand..$^{94}$ Thus, if a seller is ever going to use section 2-202 to

respect to it." Id. at 87 . The same is true in most consumer situations involving much less expensive items than automobiles.

92. See Palmer, supra note 90 , at 835 :

In countless cases the extrinsic evidence has been rejected out of hand, merely on the ground that it "varies the terms of the writing," without inquiry into whether the writing was intended to be a complete and accurate embodiment of the agreement. . . [E]xplicitly or otherwise the court holds that the writing itself is conclusive on the issue: an appearance of completeness is regarded as decisive.

93. See Williams v. Walker-Thomas Fumiture Co., 350 F.2d 445, 449 (D.C. Cir. 1965); Henningsen v. Bloomfield Motors, Inc., 32 N.J. 358, 399-400, 161 A.2d 69, 92-93 (1960).

94. The importance of the parties' intentions under section 2-202 is emphasizcd in several cases. See, e.g., Stern \& Co. v. State Loan \& Fin. Corp., 238 F. Supp. 901 (D. Del. 1965); McDown v. Wilson, 426 S. W.2d I12 (Mo. App. 1968); Holland Furniture Co.v. Hcidrich, 7 Pa. D. \& C. 204 (C.P. Luzerne Co. 1955). 
protect his contract of adhesion, he has an affirmative duty in many circumstances to explain the provisions of the writing.

One of the most difficult and common problems for the consumer's attorney is that of warranties. Are disclaimer or limitation of warranty clauses in the contract of adhesion enforceable against the consumer? The following discussion will examine the seller's affirmative duty to explain the terms of the contract within this context.

In Hunt v. Perkins Machinery $C{ }^{95}$ the contract disclaimed all warranties including the warranties of merchantability and fitness. The disclaimer, appearing third in a list of terms and conditions, was in bold face capitals on the back of the order form. On the face of the order, also in bold face capitals, was the statement: "BOTH THIS ORDER AND ITS ACCEPTANCE ARE SUBJECT TO 'TERMS AND CONDITIONS' STATED IN THIS ORDER." The plaintiff, suing for breach of implied warranties of merchantability and of fitness for a particular purpose, was awarded a judgment in the trial court.

The Supreme Judicial Court of Massachusetts upheld the judgment on the basis of section 2-316(2) of the Code, which provides that exclusions of warranties of merchantability -if in writing-and fitness-which "must [always] be by a writing"-must be "conspicuous."9s The court stated that

the provisions on the front of the purchase order did not make adequate reference to the provisions on the back of the order to draw attention to the latter. Hence, the provision on the back of the order cannot be said to be conspicuous although printed in an adequate size and style of type. The disclaimer was not effective. ${ }^{97}$

This case shows the importance of section 2-316(2) as a specific tool to allow proof of parol warranties of merchantability and fitness. ${ }^{98}$ It is, however, far more important for its more general implications.

\section{352 Mass. 535, 226 N.E.2d 228 (1967).}

96. UCC § 2-316(2).

97. 352 Mass. at 541,226 N.E.2d at 232.

98. Another available technique in sueh a situation is a declaration that the provisions in question are unconscionable. See UCC $\S 2-302$. In terms generally applicable to the consumer transaction under consideration, Judge Skelly Wright has stated:

Unconscionability has generally been recognized to include an absence of meaningful choice on the part of one of the parties together with contract terms which are unreasonably favorable to the other party. . . . In many cases the meaningfulness of the choice is negated by a gross inequality of bargaining power. The manner in which the contract was entered is also relevant to this consideration. Did each party to the contract, 
The first Comment to section 2-316 suggests the rationale for the requirement of "conspicuousness":

[This section] seeks to protect a buyer from unexpected and unbargained language of disclaimer by denying effect to such language when inconsistent with language of express warranty and permitting the exclusion of implied warranties only by conspicuous language or other circumstances which protect the buyer from surprise."

What is at the heart of this protection of the buyer from surprise? $1 \mathrm{t}$ is submitted that this provision reflects the emphasis on intent which is inherent in the Code's concept of the "bargain": if the "conspicuous" disclaimer has come to the attention of the buyer, and it remains in the contract, there is a strong presumption that it was bargained for and that both parties intended that it be a part of the contract. But in the normal course of things, how often will this be the case? ${ }^{100}$

The operation of the parol evidence rule in this specific context was seen very clearly by the court in Admiral Oasis Hotel Corp. $v$. Home Gas Industries, Inc. ${ }^{101}$ Following representations by the defendant's salesman that the defendant's air conditioners "were well constructed and would perform the work of cooling the rooms of the hotel," the plaintiff entered into an oral contract for the purchase of

considering his obvious education or lack of it, have a reasonable opportunity to understand the terms of the contract, or were the important terms hidden in a maze of fine print and minimized by deceptive sales practices? . . . In such a case the usual rule that the terms of the agreement should not be questioned should bc abandoned and the court should consider whether the tcrms of the contract are so unfair that enforcement should be withheld. Williams v. Walker-Thomas Furniture Co., 350 F.2d 445, 449-50 (D.C. Cir. 1965).

See generally Leff, Unconscionability and the Code-The Emperor's New Clause, $115 \mathrm{U}$. PA. L. REv. 485, $521-22$ (1967); Speidel, Unconscionability, Assent and Consumer Protection, 31 U. PrtT. L. Rev. 359 (1970).

99. UCC \& 2-316, Comment 1 (emphasis added). "Section 2-316, then, not only says that warranties may be disclaimed, but it says how one should go about doing so, in rather impressive detail and with surprising particularity. It is obvious that the vice is 'surprise,' and thus even the word "conspicuous' at the very heart of the provision is not left to speculation." Lcff, supra note 98 , at 521-22.

100. The tug of war between warranties and the parol evidence rule is not new. One commentator has noted: "As legal devices to promote fair and easy commercial intercourse, warranties on the one hand and disclaimcrs and the Parol Evidence Rule on the other pull in opposite directions, and to the extent that the lattcr are improperly extended, the cffective utilization of warranties is unjustifiably diminished." Note, Warranties, Disclaimers and the Parol Evidence Rule, 53 Colum. L. REv. 858, 859 (1953). Thus, the parol evidence rule has often caused injusticc under the guise of imparting certainty and stability to commercial transactions. $C$ f. id.

101. 68 Ill. App. 2d 297, 216 N.E.2d 282 (1966). 
hotel room air conditioners from defendant. When the air conditioners did not work, plaintiff filed suit against both defendantseller and the manufacturer. The manufacturer pointed out, by way of defense, that it gave an express warranty which specifically negated recovery for any special, indirect, or consequential damages. After noting that the disclaimer came when the machines were delivered, well after the contract had been entered into and too late to become part of the contract, the court continued:

Even if the oral contract did contain-some reference to a warranty, it is extremely doubtful that the buyer would be bound by the disclaimer of warranty unless he had specifically been made aware that such a disclaimer existed as part of this warranty. As was said in Henningsen v. Bloomfield Motors, supra, in the absence of fraud, one who entered into a contract without making himself fully aware of its import cannot later relieve himself of the consequences. That case, however, held that where a written contract held a disclaimer of warranties, and such a disclaimer had not been called to the attention of the buyer, the buyer could not be bound. The fact that in that case the contract was written while in the case at bar it was oral, would makc no difference.

In short, when one purchases a product, he has a right to assume that it will be fit for normal use. A seller or manufacturer cannot disclaim its responsibility for the product unless the buyer is made fully aware that he takes the product subject to such conditions. ${ }^{102}$

The case capsulizes the conclusion above that the disclaimer clause should be held to be nonexistent in almost every consumer case. ${ }^{103}$

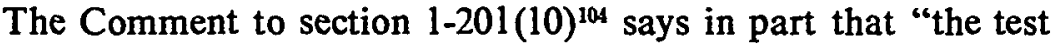
[for determining conspicuousness] is whether attention can reasonably be expected to be called to [a term]." ${ }^{105}$ Given this test, the quality of conspicuousness is not merely a question of the size and color of the type, although these are the only examples given in the statute itself; rather, the statute only indicates "some of the methods

102. Id. at 306,216 N.E.2d at $286-87$. While Henningsen was decided on pre-Code grounds, the court thought that its opinion was "in keeping with" section 2-316. Id. at 306, 216 N.E.2d at 286.

103. See also Hertz Commercial Leasing Corp. v. Transportation Credit Clearing House, 59 Misc. 2d 226, 298 N.Y.S.2d 392 (N.Y. County Ct. 1969), discussed at note 128 infra.

104. UCC $\S 1-201(10)$. The section provides that "[a] term or clause is conspicuous when it is so written that a reasonable person against whom it is to operate ought to have noticed it. . . . Language in the body of a form is 'conspicuous' if it is in larger or other contrasting type or color. . . Whether a term or clause is 'conspicuous' or not is for decision by the court.' Id.

105. UCC \& 1-201(10), Comment 10. 
of making a term attention-calling." 108 Thus, conspicuousness must be a question of negotiation or bargaining. The buyer must be given the opportunity to become aware of the terms of the contract. One-but not the only-method of accomplishing this is by forcing the seller to present the more oppressive terms in such a way that the buyer's attention will be drawn to them, achieving the necessary "notice."

This requirement of notice is emphasized by the language in section 1-201(10) which provides that a term is conspicuous "when it is so written that a reasonable person against whom it is to operate ought to have noticed it." In attempting to characterize "notice," section 1-20I(25) provides that a person has "notice" of a fact when he has actual knowledge of it, when he has received a notice or notification of the fact, or when he has reason, from all the facts and circumstances known to him at the time in question, to know that the fact exists. ${ }^{107}$

\section{Section 1-20I(26) adds that}

a person "notifies" or "gives" a notice or notification to another by taking such steps as may reasonably be required to inform the other in ordinary course whether or not such other actually comes to know of it. A person "receives" a notice or notification when

(a) it comes to his attention . . . . ${ }^{103}$

Even though the definition of "conspicuous" in section 1-201(10) refers to "written" terms or clauses, it is clear from the use of the word "notice" in the definition and from the comment to the section that the problem of conspicuousness is really a function of notice, not merely form; this in turn, as earlier stated, is a question of intent and bargain. Taking the definitional components of sections 1-201(25) and (26) in the consumer context, the following conclusions emerge: unless the presence of a disclaimer clause is specifically brought to their attention prior to the signing of the contract, few-if any-consumers would ever have "actual knowledge" 108 of the fact that the contract contains a disclaimer of warranties, much less of what it means; since the seller who slips one over on the consumer has

106. Id.

107. UCC § 1-201(25).

108. UCC \$1-201(26). The somewhat circular nature of the Code provisions and definitions concerning "notice" is demonstrated and criticized in Mellinkoff, The Language of the Uniform Commercial Code. 77 YALE L.J. 185, 200-03 (1967).

109. UCC \& 1-201(25)(a). 
not taken "such steps as may be reasonably required to inform [the consumer] in ordinary course,"110 the consumer has not "received a notice or notification of" the fact of the presence of the disclaimer;"11 and it would appear quite difficult to argue, as the seller would in the ordinary consumer transaction, that "from all the facts and circumstances known to [the consumer] at the time in question [the consumer] has reason to know" that the fact of the disclaimer exists. ${ }^{112}$ Steps which are reasonably adequate to give notice in one case may be insufficient in another situation. When the seller's ordinary course of business involves a clientele for whom the written word is not an ordinary means of communication beyond that which is necessary for daily existence, the steps which are "reasonably required to inform" are more than red ink and boldface type. The reasonable steps in such cases must in fact be verbal explanations of the contract terms. Indeed, it is very easy to conclude that the situations in which the purchaser understands fully the implications of what he is signing are so infrequent that an affirmative obligation should be uniformly imposed upon the seller to offer a detailed and understandable explanation of the more rigorous terms of the contract. ${ }^{113}$

Not unknown at the common law, this "read-it-aloud" concept is best illustrated by a surprisingly hoary case ${ }^{114}$ involving the sale of a farm machine. In making the sale, the seller's agent told the illiterate defendant that the paper he was signing-a printed purchase order-was simply a paper which would enable him to get the machine, deliberately withholding information of its contents. One of its provisions required that the buyer would have to follow certain procedures in order to take advantage of the warranties contained therein. When the seller brought suit on two promissory notes given to evidence the purchase price, the buyer raised a defense and counterclaim based on an alleged breach of warranty. The court found that the "suppression of material facts" and the "withholding of material information" was fraud, holding in favor of the defendant on both his defense and his counterclaim. ${ }^{115}$

110. UCC \& 1-201(26).

111. UCC $\S 1-201(25)(b)$.

112. UCC \& 1-201 (25)(c).

113. See the language of Williams v. Walker-Thomas Furniture Co. appearing in note 98 supra.

114. Parsons Band Cutter \& Self-Feeder Co.v. Haub, 83 Minn. 180, 86 N.W. 14 (1901).

115. While a cynic might distinguish this case as a "buyer-couldn't-read-case" not 
In another more recent case, ${ }^{116}$ a seller brought suit against his buyer for nonpayment on a contract which provided that "our guarantee of quality does not extend beyond taking goods back at invoice price if claim is made within ninety days from date of shipment." In holding this provision ineffective to accomplish its intended purpose the court stated:

Both the president and vice-president and treasurer of [the buyer] testified that they had not previously observed such stipulation and it was never called to their attention. It is so located as to easily escape attention. Certainly it could not be said as a matter of law that [the buyer] should have been aware of the stipulation. "The rule in this state is that for such a clause to be applicable in any case it must be shown that it was brought to the attention of the purchaser."117

Other cases, some under the Uniform Commercial Code, lead to the same conclusion. ${ }^{118}$

In summary, combination of sections 2-202 and 2-316 with the notice provisions of the Code requires that disclaimer of warranty provisions be specifically brought to the attention of the consumerpurchaser. If this means that they must be read out loud and perhaps even explained, then so be it.

\section{Parol Evidence and Express Warranties}

Thus far our discussion has been primarily limited to implied warranties. But what of express warranties?"19 In dealing with this problem it will be useful to set forth a common hypothetical situation. The consumer has signed a form contract for the purchase of a television set after oral statements by the seller that the merchandise is guaranteed to be new and that it will receive all the UHF channels in

applicable to the typical "literate" consumer, one may wonder whether anyone, able to read or not, is functionally literate when it comes to reading and comprehending the run-of-the-mill warranty disclaimer clause.

116. Reliance Varnish Co. v. Mullins Lumber Co., 213 S.C. 84, 48 S.E.2d 653 (1948).

117. Id. at 97,48 S.E.2d at 659.

118. See, e.g., Smith v. Regina Mfg. Corp., 396 F.2d 826 (4th Cir. 1968); Mack Trucks, Inc. v. Jet Asphalt \& Rock Co., 246 Ark. 99, 437 S.W.2d 459 (1969); Cherokce Inv. Co. v. Voiles, 166 Colo. 270, 443 P.2d 727, 729 (1968); Dailey v. Holiday Distrib. Corp., 260 lowa 859, 151 N.W.2d 477, 485 (1967); Zabriskie Chevrolet, Inc. v. Smith, 99 N.J. Super. 44 1, 447, 240 A .2d 195, 198-99 (1968). For a discussion of similar earlier cases, see Henningsen v. Bloomfield Motors, Inc., 32 N.J. 358, 392-99, 161 A.2d 69, 87-90 (1960).

119. As used in this context "warranty" means a "promise that something will happen in the future, usually without the necessity of further performance by the promisor." Swcet, supra note 70 , at 881 n.17. For a discussion of the application of this definition to a typical consumer transaction, see $i d$. 
the vicinity. The contract contans both a disclamer of all warranties, express or implied, and an integration clause. Although the set turns out to be capable only of receiving the VHF channels, the seller refuses to "make good" on his warranty. May the buyer, either in an action brought by him for b reach of contract, or by way of defense to an action by the seller for default in the installment payments, introduce evidence of the seller's statements?

Section 2-313 provides in part:

(1) Express warranties by the seller are created as follows:

(a) Any affirmation of fact or promise made by the seller to the buyer which relates to the goods and becomes part of the basis of the bargain creates an express warranty that the goods shall conform to the affirmation or promise.

(b) Any description of the goods which is made part of the basis of the bargain creates an express warranty that the goods shall conform to the description.

(2) It is not necessary to the creation of an express warranty that the seller use formal words such as "warrant" or "guarantee" or that he have a specific intention to make a warranty, but an affirmation merely of the value of the goods or a statement purporting to be merely the seller's opinion or commendation of the goods does not create a warranty. ${ }^{120}$

The comments to this section indicate beyond peradventure that the draftsmen intended that the parol evidence rule should be used infrequently to exclude parol evidence of express warranties made by the seller during the negotiations leading up to the sale. ${ }^{121}$ The same is true of integration clauses: " 'Express' warranties rest on 'dickered' aspects of the individual bargain, and go so clearly to the essence of that bargain that words of disclaimer in a form are repugnant to the basic dickered terms." 122 Further, "any fact which is to take such affirmations [of fact], once made, out of the agreement requires clear affirmative proof." ${ }^{23}$ Comment 4 sets out the essence of the draftsmen's purpose with specificity:

In view of the principle that the whole purpose of the law of warranty is to determine what it is that the seller has in essence agreed to sell, the policy is adopted of those cases which refuse except in unusual circumstances to

120. UCC \& 2-313.

121. "The precise time when words of description or affirmation are made . . is not material. The sole question is whether the language. . . [is] fairly to be regarded as part of the contract." Id., Comment 7.

122. Id., Comment 1 .

123. Id., Comment 3 . 
recognize a material deletion of the seller's obligation . . . A clause generally disclaiming "all warranties, express or implied" cannot reduce the seller's obligation with respect to such description and therefore cannot be given literal effect under Section 2-316.124

Finally, if the warranty was a part of the bargain to which the buyer thought he was agreeing when he signed the contract, it remains part of the contract. ${ }^{125}$ Thus, we return to the original question: does section 2-202 preclude proof of the parol warranty made by the seller in the hypothetical above? More specifically, does the inclusion of an integration clause have the effect of invoking that part of section 2$316(1)$ which refers to section 2-202?'126

Given the somewhat obscure draftsmanship and the generally unarticulated relationship between sections $2-202$ and $2-316,{ }^{127}$ the

124. Id., Comment 4; accord, Klein v. Asgrow Seed Co., 246 Cal. App. 2d 87, 102 n.8, 54 Cal. Rptr. 609, 619-20 n.8 (1966).

125. What statements of the seller have in the circumstances and in objective judgment become part of the basis of the bargain? . . . [A]ll of the statements of the seller do so unless good reason is shown to the contrary. . . . Even as to false statements of value, however, the possibility is left open that a remedy may be provided by the law relating to fraud or misrepresentation. UCC $\$ 2-313$, Comment 8 .

126. Section 2-316(1) provides:

Words or conduct relevant to the creation of an express warranty and words or conduct tending to negate or limit warranty shall be construed wherever reasonable as consistent with each other; but subject to the provisions of this Article on parol or extrinsic evidence (Section 2-202) negation or limitation is inoperative to the extent that such construction is unreasonable. UCC $\S 2-316(1)$ (emphasis added).

127. The worrisome nature of the draftsmanship is best articulated in R. DuESENBERG \& $L$. KING, supra note $56, \S 6.06$, at $6-13$ to 6-15. Acknowledging that the answer "is not entirely free from doubt," the authors indicate that the parol evidence rule may not exclude testimony relating to the alleged oral warranty: "The parol evidence rule would seem to exclude the warranty, but the warranty provisions of Section 2-316(1) would seem to have the policy of including the warranty." Id. at 6-13. In the situation where the oral warranty and the language in the written contract cannot reasonably be construed together, the authors note that section 2202

would seem to say that if the writing is intended to give the final expression of the intent or contract of the parties, then no evidence of prior or contemporaneous terms may be admissible. Of course, it would always be left open for a court to find that the writing itself was not intended as the final expression of the parties. This finding could be based solely on the fact of the existence of the prior oral express warranty. This would seem like circular reasoning by finding that the express oral warranty made the written contract not conclusive, final or complete and, therefore, permitting the express oral warranty to be admissible in evidence. Yet this is the result that seems intended by the Code, or, at least, if not intended one that is left open to a court to achieve. Id. at 6-14.

On the other hand, they conclude that a properly drafted disclaimer of warranty would preciude the introduction of parol evidence. Id. at 7-36 to 7-37. Finally, thcy note the particular relative disadvantage of the buyer in connection with a disclaimer clause in the typical consumer transaction: first, inclusion of such a clause does little to endanger the sellers' public relations 
courts' trouble with this problem is not surprising. As in so many other areas of contract law, however, the courts have either tried to present some coherent rationale for a decision in favor of the consumer, or they have begun to indulge in the type of fiction frequently appearing in the law.

In declining to give effectiveness to language of disclaimer, the courts have found either that the oral express warranty was part of the bargain of the parties or, conversely, that the disclaimer clause was not part of the bargain. These twin conclusions lead to the admissibility of parol evidence:

The [disclaimer] clause . . . does not modify or exclude . . . any express warranties, if any were made to defendant by the plaintiff during the course of the negotiations leading to the contract. Whether such express warranties were made, . . or modified by or excluded by the actions of the parties prior to the contract (U.C.C. § 2-316(3)(b),(c)) are matters of fact as to which the parol evidence rule ... may not be applicable ... by reason of the legal nonexistence of the disclaimer clause. ${ }^{123}$

The desire of the courts to give effect to the first comment to section 2-316, thereby preserving both parties' "bargained" expectations, ${ }^{120}$ is also clear from the opinion in Walcott \& Steele, Inc. $v$. Carpenter. ${ }^{130}$ In that case, each bag of cotton seeds which the plaintiff purchased from defendant had an attached tag showing germination to be eighty percent. Yet the wording at the bottom of the invoice sent to plaintiff stated:

NON-WARRANTY. [Defendants] Give no Warranty, Express or Implied. As to Description, Productiveness, or Any Other Matter of Any Seeds That

\footnotetext{
"because it is doubted that the language will be fully understood by the consumer," from the commercial standpoint, the inclusion of such a clause will pose no real problem, because it will "go unnoticed or will be deemphasized by the buyer [seller?]; or . . . [t]he clause will be in general use among sellers and the buyer will have no real place to turn." Id. at 7-37. This same kind of "logic" has led the courts to view form contracts and disclaimers more critically and, hopelully, will lead them to further expand the univcrse of evidence not subject to exclusion under section 2-202. See also Duesenberg, The Manufacturer's Last Stand: The Disclaimer, 20 Bus. LAw. 159 (1964), where the author noted that the diselaimer-although justified on a risk-control basis-is frequently used deceptively as a method of risk elimination. Id. at 162 .

128. Hertz Commercial Leasing Corp.v. Transportation Credit Clearing House, 59 Misc. 2d 226, 231, 298 N.Y.S.2d 292, 298, (N.Y. County Ct. 1969). Cf. Ezer, The Impact of the Uniform Commercial Code on the California Law of Sales Warranties, 8 U.C.L.A. L. REv. 281 (1961). "[E]xpress oral warranties not inconsistent with any written tcrm will become admissible against the reneging seller unless the trial court finds the document was intended to be an exhaustive statement of the entire agreement." Id. at 312 .
}

129. See text accompanying note 99 supra.

130. 246 Ark. 436 S.W.2d 820 (1969). 
We Sell and We Will Not in any Way Be Responsible for the Crop. Our

Liability in all Instances Is Limited to the Purchase Price of the Seed. ${ }^{131}$

When the seed only germinated at twenty-seven percent, the plaintiffbuyer brought this suit against the seller. Concluding first that, as a matter of law, the tag attached to each bag created an express warranty that the seed would germinate at eighty percent, the court went on to hold that the disclaimer was "unbargained for" and therefore not a part of the contract between the parties. This led inevitably to the conclusion that the negation of the express warranty was inoperative, since the disclaimer and the express warranty could not reasonably be construed as consistent. ${ }^{132}$

Taken in conjunction with Luther Williams, Jr., Inc. $v$. Johnson, ${ }^{133}$ these cases clearly establish that neither a disclaimer of warranties nor an integration clause will prevent the introduction of parol evidence of warranties made during the course of negotiations. ${ }^{134}$ This conclurion, the courts reason, must naturally follow from the emphasis of the Code's sections and comments upon the bargain and the knowledge of the parties. ${ }^{135}$ That is, section 2-202 forbids evidence of prior or contemporanecus agreements only if the parties intend the writing to be a final expression of their agrcement. Since intent is a question of fact which cannot be discovered by looking at the writing alone, an allegation by the buyer that he did not intend the writing to be the total integration of the agrcement or that the disclaimer or

131. Id. at $\longrightarrow 436$ S.W. $2 \mathrm{~d}$ at 822.

132. Id. at $\longrightarrow 436 \mathrm{~S} . W .2 \mathrm{~d}$ at 823 (interpreting UCC § 2-316(1)). Cf. Berk v. Gordon Johnson Co., 232 F. Supp. 682 (E.D. Mich. 1964).

133. 229 A.2d 163 (D.C. Ct. App. 1967). A discussion of the case appears in the text accompanying notes 59-65 supra.

134. But cf. Green Cherrolet Co.v. Kemp, 241 Ark. 62, 406 S.W.2d 142 (1966); First Nat'1 Bank v. Husted, 57 Ill. App. 2d 227, 205 N.E.2d 780 (1965).

135. The courts are starting to use other techniques in order to reach the same result. For example, in Walsh v. Ford Motor Co., 59 Misc. 2d 241, 298 N.Y.S.2d 538 (N.Y. Sup. Ct. 1969), an action for personal injuries suffered as a result of an accident caused by an allegedly defective car, the court held that "the contractual provisions pleaded here disclaim all warranties, and at the same time would limit the remedies available for a breach of warranty, and attempts to do both create an ambiguity and are unreasonable if that is what was intended under the contract and the defense as pleaded . . . Id. at 243, 298 N.Y.S. at 540. Compare Leveridge v. Notaras, 433 P.2d 935 (Okla. 1967). This thought is apparent in Note, Warranties, Disclaimers and the Parol Evidence Rule, 53 CoLUM. L. REv. 858 (1953):

Since the Code's proposals are aptly designed to preclude misapplication of the Parol Evidence Rule and to prevent enforcement of disclaimers whieh the buyer had no intent to make, adoption of the Code will revitalize the commercial utility of warranties. The cffect of bargaining inequality will be lessened, honesty of the market will be enhanced, and the bargain to which the parties liave agreed will be enforced. $I d$. at 871 . 
integration clause was inserted by the seller to serve his own interest should serve to circumvent the prohibitions contained in sections 2$316(1)$ and 2-202. The facts and circumstances which must be examined to determine intent should include the relative bargaining strength of the parties and the social, economic, and educational background of the buyer.

Once it has been determined that the buyer did not intend to accept the disclaimer clause as part of the "bargain," only the conflict between the oral warranty and the written disclaimer of warranties in the contract remains for resolution. In resolving this issue the courts have been quick to find that the exclusion of warranties clause was not part of the agreement-was not intended by the buyer-and is therefore not protected from contradiction by parol testimony. Then the oral warranty itself must be proved in the usual manner to the satisfaction of the trier of fact.

This analysis finds further support in Comment 2 to section 2-316, which states that "[t]he seller is protected under this Article against false allegations of oral warranties by its provisions on parol and extrinsic evidence." 138 Apparently convinced that the seller received adequate protection against false allegations by section $2-202$, the draftsmen gave him no further protection in section 2-316(1); rather, they appear to have "incorporated" the provisions of section 2-202 into section 2-316(1), this time with specific reference to oral express warranties. The conflict between an alleged express warranty and a disclaimer thereof in the written contract is to be judged by section 2202 standards.

The attitude of the Code's draftsmen toward express warranties is portrayed in Comment 1 to section 2-313: express warranties go to the "essence" of the bargain; disclaimers are "repugnant" to "basic dickered terms." "137 Apparently convinced that express warranties are the only bargaining advantage some buyers have, the draftsmen seek to prevent the seller from routinely disregarding his express warranties through a boilerplate disclaimer in his sale form. ${ }^{138}$

Only with all this in mind may the reference to section 2-202 contained in section 2-316(1) be construed. Does the subjection of express parol warranties to scrutiny under section 2-202 mean that no

136. UCC \$2-316, Comment 2 (making cross reference to section 2-202).

137. UCC $\$ 2-313$, Comment 1 .

138. Cf. UCC $\S 2-313$, Comment 4 , which contends that "the probability is small that a real price is intended to be exchanged for a pseudo-obligation." 
oral warranty may ever be proved if it is contrary to a written "contractual" negation or limitation of warranties? If the answer to that question were yes, Comment 2 to section 2-316 would not imply that there are cases in which oral warranties could be proved; by limiting the function of section 2-202 to protecting sellers against "false allegations of oral warranties," the draftsmen implicitly recognize that scction 2-202 will not protect sellers from "true" allegations of oral warranties. If the disclaimer was not "intended" by both parties, the allegation of oral warranty may be true, and section 2-202 will not protect the seller. This conclusion is in all respects consistent with the draftsmen's belief that express warranties often form an integral part of the bargain of the parties. Realism will prevail over boilerplate.

\section{CONCLUSION}

This article has sought to show that the Uniform Commercial Code's parol evidence rule is substantially different from its common law predecessor. While the common law rule operated to the distinct disadvantage of the consumer and was an essential ingredient in the campaign of some sellers to bilk their buyers, the rule's operation under the Code is not so one-sided. In fact, section 2-202 should operate affirmatively to permit the consumer to introduce evidence of oral warranties and promises made during the course of negotiations leading up to his purchase, thereby equalizing the bargaining power of seller and consumer. Recognizing that the parol evidence rule has often been used to create injustice rather than to prevent it, the courts should honor the attempt by draftsmen of the Code to turn the situation around and provide a rule which operates fairly for buyer and seller alike. 